\title{
DETERMINATION OF HETEROSIS AND HETEROBELTIOSIS VALUES OF SALT-TOLERANT SUMMER SQUASH (Cucurbita pepo L.) GENOTYPES AND GENETIC RELATIONSHIPS OF PARENTAL GENOMES
}

\author{
KARIPÇİN, M. Z. $.^{*}-$ INAL, B. ${ }^{2}$ \\ ${ }^{l}$ Department of Horticulture, Faculty of Agriculture, Siirt University \\ Siirt, 56100 Turkey \\ ${ }^{2}$ Department of Agricultural Biotechnology, Faculty of Agriculture, Siirt University \\ Siirt, 56100 Turkey \\ *Corresponding author \\ e-mail: zkaripcin@gmail.com; phone: +90-4-842-241-111 \\ (Received 29 ${ }^{\text {th }}$ Apr 2017; accepted $1^{\text {st }}$ Aug 2017)
}

\begin{abstract}
This study was carried out to determine the heterosis and heterobeltiosis values in F1 hybrids which are obtained through hybridization of salt-tolerant genotypes in summer squash (Cucurbita pepo L.). The materials used were the promising hybrid combinations and their parents, which are previously reported among the salt-tolerant genotypes by detecting the influence of parents on heterosis and heterobeltiosis values in advanced hybridization studies. Eight domestic summer squash genotypes (Tutluca 1, Tutluca 2, Halfeti 1, Halfeti 2, Bozova Mrkz, Yaslıca, Konak and Şanlıurfa Mrkz), were chosen from salt-tolerant genotypes and $28 \mathrm{~F} 1$ hybrids obtained through hybridization of these genotypes. The heterotic influences were remarkably important, and it was possible to get promising hybrids in terms of examined traits. Parents were evaluated for plant length $(\mathrm{cm})$, stem diameter $(\mathrm{mm})$, plant width-spread $(\mathrm{cm})$, number of leaves (number), 50\% female flowering time (day), yield $(\mathrm{kg})$, parental and hybrid heterosis and heterobeltiosis values (\%), and parental contribution to heterosis and heterobeltiosis of F1 hybrids. The highest heterotic effect was determined in the summer squash yield traits. In the yield, a maximum of $32.67 \%$ heterosis and $24.36 \%$ heterobeltiosis values were obtained. Additionally, genetic relationships of parental genotypes based on chloroplast DNA sequence analysis were compatible with results of heterosis and heterobeltiosis.
\end{abstract}

Keywords: Cucurbita pepo L., abiotic stress, breeding, hybridization, trnL-F, genetic similarities

\section{Introduction}

Among all agricultural products, vegetable production in the world reached its highest rate (45\%) between 1985 and 1995 (Harrison, 2002). Turkey's fruit and vegetable products have an important role in both industry and in exports. Agricultural products constitute approximately $25 \%$ of Turkey's exports. However, vegetables share in this value is only around $2 \%$ (Turkstat, 2015). Eating habits are changing in favor of vegetables parallel to cultural and economic developments in Turkey, as in many other countries throughout the world. Fruits and vegetable crops have a remarkable place in the diet of developed countries (Skreden et al., 2017). Summer squash (Cucurbita pepo L.) which has an annual production of $137,000 \mathrm{Hg} / \mathrm{Ha}$ (Anonymous, 2013), is produced in a wide number of climate zones, has significant economic value (Paris, 1986). Summer squash has a wide variation in terms of size, color and shape of the fruit (Paris, 1986). C. pepo is divided into eight groups in terms of fruit shape, six groups in terms of fresh consumption of the fruit and five groups based on the thickness of the fruit skin. 
The most distinctive feature of summer squash from other squash types is that fruits are almost always smooth (Paris, 2008).

Plant breeders' ultimate target is high production/yield. To widen genetic variation for breeding, variety expansion and hybridization are carried out. The most important criteria for hybridization is to select the most suitable parents for this purpose in early generations. For a breeder trying to develop a variety, finding heterosis values means the work is well-directed, and may produce a variety in a shorter time period. A successful breeding programme is based on accurate selection of the material used. Determination of heterosis values is important to develop new and strong squash cultivars (Stuber, 1994). Hallauer and Miranda (1988) calculated heterosis values according to potential gene combinations of parents. The best combinations were achieved from the hybridization between the types and lines in different heterotic groups. The width of the heterotic pattern in genetic sources affected the degree of heterosis level positively.

Heterosis, defined as the superiority of F1 over its better parent, will occur when F1 $>\mathrm{P} 1$, if it is the better parent for the property under consideration, or F1 $<\mathrm{P} 2$ if $\mathrm{P} 2$ is the better parent. Clearly, $\mathrm{P} 1$ will be the better parent where superiority is equitable to a higher value for the mean phenotype, e.g., higher yield, whereas P2 will be the better parent where it is equitable to a lower value for the mean phenotype, e.g., fewer days to reach maturity. Heterosis of the first kind, which called positive, will occur when;

$$
F 1-P 1=[F 11 / 2(P 1+P 2)]-[1 / 2(P 1-P 2)]
$$

Heterosis of the second kind, which is called negative, will occur when;

$$
F 1-P 2=[F 1-1 / 2(P 1+P 2)]+[1 / 2(P 1-P 2)]
$$

The heterosis effect in summer squash is seen primarily in the number of fruits per plant and in earliness of fruit development (Curtis, 1939). Curtis (1941) reported heterosis in the earliness of fruit harvest $114 \%$ over the parental mean and $87 \%$ over the better parents mean. A comparison of nine yellow fruited F1 hybrids with three commercial varieties showed $46 \%$ advantage in earliness and 19\% in yield (Elmstrom, 1978).

The $\mathrm{F}_{1}$ must be superior to its parents to observe heterosis, whether it is also superior to all of the pure-breeding lines. Heterosis is theoretically a quadratic function of parental genetic distance (GD) at the underlying quantitative trait loci (QTL) for the trait considered (Falconer and Mackay, 1996; Melchinger, 1999). Experiments with maize showed an increase in heterosis with increasing parental GD (Moll et al., 1962; Melchinger, 1999), but they also suggested an optimum level of parental GD, after which heterosis and hybrid performance declines (Moll et al., 1965). The results provide strong evidence that epistasis plays a major role as the genetic basis of heterosis ( $\mathrm{Yu}$ et al., 1997). Programs to exploit mating systems to produce hybrids were developed in spinach (monoecious forms), cucumber (genetically controlled), squash (response to chemicals), and carrot (cytoplasmic male sterility) (Pearson, 1983).

Chloroplast DNA has been used extensively to determine the genetic similarities and differences in plants. The chloroplast trnL-F region has proven to be phylogenetically useful from the species level to the family level. It is a noncoding region that includes the trnL (UAA) intron ranging from 350 to 600 base pairs (bp) and the intergenic spacer 
between trnL (UAA) 3' exon and the trnF (GAA) gene. That sequence is in the region where the chloroplast genome does not code. It is widely used in phylogenetic research (Taberlet et al., 1991). Additionally, it comes to forefront in molecular similarity studies due to its characteristics, such as the structural stability of chloroplast DNA, haploidy (n), uniparental transferability (in general) and non-recombinant nature (Small et al., 2004). In molecular systematic studies, a phylogenetic tree is built with the data obtained while showing the degree of relationships among genotypes (Saitou and Ġmanishi, 1989).

Determination of heterosis and heterobeltiosis rates in F1 hybrids through hybridization of salt-tolerant genotypes and with DNA based relationships of parental genotypes were the main aims of this study. Since salinity is known to be a great handicap for summer squash cultivation, salt-tolerant genotypes (Tutluca 1, Tutluca 2, Halfeti 1, Halfeti 2, Bozova Mrkz, Yaslica, Konak and Şanlıurfa Mrkz) were used to evaluate the effect of parents on heterosis and heterobeltiosis.

\section{Materials and Methods}

\section{Material}

Eight different summer squash pure lines (C. pepo L.) were used in this study (Table 1). The parents were purified between 2008 and 2011. In addition to studies on their yield and yield components, a study of their tolerance to salt stress was published in 2012 (Karipcin and Sari, 2012). The summer squash parental lines used as plant material (Table 1) and hybridizations scheme without reciprocals (Table 2) are given below.

Table 1. Parental Summer squash Genotypes used in the research (C. pepo L.)

\begin{tabular}{c|c}
\hline Parent name & Origin \\
\hline Tutluca1 & Tutluca-Bozova \\
Tutluca2 & Tutluca-Bozova \\
Halfeti1 & Halfeti-Şanlıurfa \\
Halfeti2 & Şanlıurfa \\
Bozova Mrkz. & Bozova \\
Yaslıca & Yaslıca-Bozova \\
Konak & Konak-Şanliurfa \\
Şanliurfa Mrkz. & Şanlıurfa \\
\hline
\end{tabular}

Table 2. Hybridization scheme used in the research

\begin{tabular}{|c|c|c|c|c|c|c|c|c|c|}
\hline \multicolumn{2}{|c|}{$\begin{array}{l}\text { Hybridization } \\
\text { without } \\
\text { reciprocal }\end{array}$} & \multicolumn{8}{|c|}{ Parents } \\
\hline \multirow{6}{*}{ 童 } & & $\begin{array}{c}\text { Tutluca } \\
1\end{array}$ & $\begin{array}{c}\text { Tutluca } \\
2\end{array}$ & $\begin{array}{c}\text { Halfeti } \\
1\end{array}$ & $\begin{array}{c}\text { Halfeti } \\
2\end{array}$ & $\begin{array}{l}\text { Bozova } \\
\text { Mrkz. }\end{array}$ & Yaslica & Konak & \begin{tabular}{|c} 
Şanlıurfa \\
Mrkz.
\end{tabular} \\
\hline & Tutluca1 & - & $\mathrm{X}$ & $\mathrm{x}$ & $\mathrm{x}$ & $\mathrm{x}$ & $\mathrm{x}$ & $\mathrm{x}$ & $\mathrm{X}$ \\
\hline & Tutluca2 & - & - & $\mathrm{x}$ & $\mathrm{x}$ & $\mathrm{x}$ & $\mathrm{x}$ & $\mathrm{x}$ & $\mathrm{x}$ \\
\hline & Halfeti1 & - & - & - & $\mathrm{x}$ & $\mathrm{x}$ & $\mathrm{x}$ & $\mathrm{x}$ & $\mathrm{x}$ \\
\hline & Halfeti2 & - & - & - & - & $\mathrm{x}$ & $\mathrm{x}$ & $\mathrm{x}$ & $\mathrm{x}$ \\
\hline & $\begin{array}{c}\text { Bozova } \\
\text { Mrkz. }\end{array}$ & - & - & - & - & - & $\mathrm{x}$ & $\mathrm{x}$ & $\mathrm{x}$ \\
\hline
\end{tabular}




\begin{tabular}{c|c|c|c|c|c|c|c|c}
\hline Yaslica & - & - & - & - & - & - & $\mathrm{x}$ & $\mathrm{x}$ \\
Konak & - & - & - & - & - & - & - & $\mathrm{x}$ \\
Şanliurfa \\
Mrkz.
\end{tabular}

\section{Definition of Research Area}

Harran Plain is located between $36^{\circ} 47^{1}$ and $39^{\circ} 15^{1}$ east longitudes and $36^{\circ} 40^{1}$ and $37^{0} 41^{1}$ north latitudes in Şanlıurfa province in the Southeastern Anatolia, Turkey. The area is surrounded by Urfa Mountains in the North, Turkey-Syria border in the South, Tektek Mountains in the East and Fatik Mountains in the West. Harran Plain covers 225.109 ha (Anonymous, 1980) and is $410 \mathrm{~m}$ above sea level.

\section{General Soil Characteristics of the Research Area}

The research was carried out in Ikizce region. Thesoil in this region has a structure whose topography is flat or nearly flat; the whole profile is limy with a clay texture. Soil $\mathrm{pH}$ varies between $7.3-7.4$, with $1.1 \%$ organic material on the surface and $0.8 \%$ in the deep soil zones. In the soils evaluated, field capacity in dry weight, the wilting point and bulk density ranges were between 32.71-33.84\%; 21.18-22.55 and 1.37-1.41, respectively (Dinc et al., 1988; Almaca and Gok, 1997).

\section{General Climate Characteristics of Research Area}

Although Sanliurfa is in the South-Eastern Anatolia climate zone, it is under the influence of the Mediterranean climate. It has hot and dry summers, and warm winters. The precipitation increases from south to north and from west to east. According to multi-year averages, July is the warmest month $\left(46.8^{0} \mathrm{C}\right)$, while maximum precipitation $(93.1 \mathrm{~mm})$ and the highest moisture $(71 \%)$ occurs in January (Anonymous, 2012).

\section{Method}

A total of 28 hybrids were obtained from the hybridization of eight parents in 2013. Thirty six summer squash genotypes (eight parents and 28 hybrids) were evaluated under field conditions according to randomized complete block design with three replicates in 2014. The research was conducted in the GAP Agricultural Research Institute fields in Koruklu Research Station. The plants were sown in a row with $1.5 \mathrm{~m}$ x $0.5 \mathrm{~m}$ spaces with ten plants in each parcel. The first and last plants in each row was used as buffer. In every parcel, plant length $(\mathrm{cm})$, stem diameter $(\mathrm{cm})$, plant widthspread $(\mathrm{cm})$, number of leaves (number), $50 \%$ female flowering time (day), stem length $(\mathrm{cm})$ and yield $(\mathrm{kg})$ were analyzed.

\section{Heterosis and Heterobeltosis Calculations}

Heterosis level was calculated for each trait by subtracting parental average value from the F1 hybrid value and dividing this to parental average and multiplying by 100 (Fonseca and Paterson, 1968; Sari et al., 2003a; Virmani et al., 2003; Cho et al., 2004; Denizer et al., 2005; Jose et al., 2005; Ahmad et al., 2005); and by subtracting the 
superior parent's value from the F1 hybrid value, dividing it to superior parent's value and multiplying by 100 (Sari et al., 2003b; Cho et al., 2004; Denizer et al., 2005; Jose et al., 2005). That is, formulas to determine heterosis [(F1-EO/EO) $x$ 100], and heterobeltiosis ratio $[(F 1-\ddot{U} E / \ddot{U} E) \times 100]$, were used. The contribution of the parents to heterosis and heterobeltiosis was determined for evaluated traits. Differences between the genotypes were evaluated with JMP 5.1.2 software (SAS Institute, Cary, NC, USA).

\section{DNA Isolation for Molecular Studies and PCR Conditions}

DNA extraction was performed according to Karaca et al. (2005) by taking the leaf samples from each of eight parents used in this study. The quantitative features of the isolated DNA were measured with a spectrophotometer, and 1\% agarose gel was used to measure its qualitative features. PCR reaction was optimized to reproduce the trnL-F region. In order to reproduce the $\operatorname{trn} \mathrm{L}-\mathrm{F}$ region, $\mathrm{F}$ : 5'ATTTGAACTGGTGACACGAG3', R: 5'GGTTCAAGTCCCTCTATCCC3' primer pairs were used. In the tubes with a reaction of $200 \mu \mathrm{L}$, "by taking $2.5 \mu \mathrm{L}$ of reaction buffer with $10 \mathrm{X}$ ", $2.5 \mu \mathrm{L}$ from $25 \mathrm{mM} \mathrm{MgCl}, 0.4 \mu \mathrm{L}$ from $10 \mathrm{mM}$ dNTP, $1 \mu 1$ from the primer pairs with $10 \mathrm{pmol} / \mu \mathrm{L}, 0.25 \mu \mathrm{L}$ from Taq DNA polymerase, $2 \mu \mathrm{L}$ from template DNA, $15.35 \mu \mathrm{L}$ from $\mathrm{dH} 2 \mathrm{O}$, the total volume would be arranged to be $25 \mu \mathrm{L}$. To check for contamination during the PCR reaction, a negative control of non-genomic DNA was used. The PCR was adjusted to 35 cycles to remain at $94^{\circ} \mathrm{C}$ for five minutes, at $94^{0}$ $\mathrm{C}$ for one minute, at $58^{0} \mathrm{C}$ for one minute and at $72^{\circ} \mathrm{C}$ for one-minute. The last PCR product was kept at $4^{0} \mathrm{C}$. In order to see the region reproduced, $5 \mu \mathrm{L}$ DNA from PCR product was mixed with $2 \mu \mathrm{L}$ loading dye and loaded into $1.5 \%$ agarose gel. Later, with a gel scanning device, an image was taken under UV light. After appropriate band intervals were obtained, the sequence of the related region was done through service procedures.

\section{In Silico Analysis of the Sequences}

To confirm the accuracy of the sequences in the trnL-F regions of the eight parents taken in the study, BLAST analysis was carried out in the NCBI database. Sequences were then reset with Clustal X 2.0. To determine the genetic proximity and distance, these aligned sequences were subjected to MEGA 7.0 software to develop a genetic relationship tree. The Maximum Parsimony algorithm from the character-based methods was used and bootstrap, branch and bound analysis were done.

\section{Results and Discussion}

The average values of eight parents and 28 hybrids for analyzed traits, as well as heterosis and heterobeltiosis values of the F1 hybrids were given in Appendix. The parental contribution (\%) to heterosis (Table 3), and heterobeltiosis (Table 4) were calculated. The error mean square values of these examined traits and a variation analysis are given in Table 5. Considerable differences for all traits were observed between the F1s and their parents. The average plant length of the parents and hybrids were measured as $29.04 \mathrm{~cm}$ and $29.57 \mathrm{~cm}$, respectively (Appendix). The maximum heterosis value $(9.60 \%)$ occurred in the 5 x 8 (Bozova Mrkz x Şanlurfa Mrkz) hybrids (Appendix), and the highest heterobeltiosis value 
(0.61\%) was observed in the $3 \times 8$ (Halfeti-1 x Şanliurfa Mrkz.) hybrids for plant length (Appendix). An average of $3.29 \%$ heterosis in hybrids and $-23.12 \%$ of heterobeltiosis shows the heterotic effects in the material used for the plant length. The parent with the highest contribution $(6.52 \%)$ to the heterosis in plant length was Sanliurfa Mrkz, followed by the Halfeti-1 genotype (4.07\%). The lowest contribution for plant length was from Konak genotype $(0.46 \%)$ (Table 3). The highest stem diameter was measured from Sanliurfa Mrkz with $22.8 \mathrm{~mm}$, and the lowest was $15.8 \mathrm{~mm}$ from Bozova Mrkz. The stem diameter average of the parents and the hybrids were found as 19.54 and $19.82 \mathrm{~mm}$, respectively (Appendix). In terms of stem diameter, while the highest heterosis $(9.13 \%)$ was obtained from the Halfeti-2 x Bozova (4 x 5) hybrid, and the highest heterobeltiosis value $(5.08 \%)$ was from the Halfeti-1 x Şanlıurfa Mrkz (3x8) hybrid; the lowest heterosis ( $4.51 \%)$ was seen in the Halfeti-1 x Yaslica ( $3 \times 6)$, and the lowest heterobeltiosis (47.59\%) was from Yaslica x Şanlıurfa Mrkz (6 x 8) hybrids (Appendix). While Bozova Mrkz parent had the highest contribution to heterosis $(5.61 \%)$ (Table 3) with a value of $-6.31 \%$, the Halfeti-1 parent had the highest contribution to heterobeltiosis (Table 4). Plant width-spread was determined as $141.95 \mathrm{~cm}$ for parents and $146.31 \mathrm{~cm}$ for F1 hybrids, and the highest heterosis value $(16.18 \mathrm{~cm})$ was from the Tutluca-2 x Şanliurfa Mrkz hybrid (Appendix). The lowest heterosis $(8.03 \%)$ was obtained from Halfeti-1 x Halfeti-2 (3 x 4) hybrid combination (Appendix). According to heterobeltiosis values, the highest and lowest values were obtained as 5.62\% from the Halfeti-1 x Şanliurfa Mrkz (3 x 8) and $-37.66 \%$ from the Tutluca-2 x Bozova Mrkz ( 2 x 5) hybrids (Appendix). When the parental contribution to heterosis and heterobeltiosis are analyzed for plant width-spread, it is understood that the Şanliurfa Mrkz parent gives the highest contribution to heterosis and heterobeltiosis with $(12.43 \%,-2.08 \%)$ (Table 3 and Table 4). The average number of leaves for the parents was 47.21 pieces/plant, while for hybrids 50.03 pieces/plant; with a value of 19.13 pieces/plant Şanlıurfa Mrkz parent (number 8) having the highest heterosis value, and the lowest heterosis value ($7.05 \%$ ), belonged to the Halfeti-1 x Yaslica hybrid (Appendix). The highest contributions for number of leaves to heterosis and heterobeltiosis were $10.44 \%$ and -8.28 from the Şanliurfa Mrkz, and from Yaslica parents with a $2.71 \%$ heterosis value, and Bozova Mrkz parent with a $-31.81 \%$ heterobeltiosis value takes the last place in the order (Table 3 and Table 4). According to 50\% female flowering time, the parental average is 27.86 days; and hybrids average is 28.37 days (Appendix). The heterosis values for $50 \%$ female flowering time is given in Appendix. As reported in the Appendix, for 50\% flowering time, the highest heterosis value (19.21\%) belongs to the Tutluca-1 x Halfeti-1 hybrid (1x3) and the lowest heterosis value (-21.25\%) belongs to the Halfeti-1 x Şanliurfa Mrkz (3 x 8) hybrid. When the contribution of parents to heterosis (Table 3) and heterobeltiosis (Table 4) were examined for the $50 \%$ female flowering time trait, it was seen that the highest contribution to heterosis $(5.28 \%)$ was from the Halfeti-2; the lowest contribution to heterosis $(-4.9 \%)$ was from the Şanliurfa Mrkz, and the highest contribution margin to heterobeltiosis $(-10.63 \%)$ belongs to the Tutluca-2 parents. The lowest contribution to heterobeltiosis $(-29.02 \%)$ was again from the Şanlıurfa Mrkz genotype. When stem length data were examined, the average of the hybrids $(34.74 \mathrm{~cm})$ was higher than that of the parents $(32.43 \mathrm{~cm})$. Among the parents the highest value $(36.7 \mathrm{~cm})$ belongs to the Bozova Mrkz. On the other hand, among 
hybrids, the highest average value $(40.99 \mathrm{~cm})$ was from the Tutluca-1 x Yaslica (1 x 6) hybrid (Appendix). It was found that the heterosis value of the $4 \times 8$ hybrid $(26.78 \%)$ was the highest, and $3 \times 4$ hybrid was the lowest $(-22.62 \%)$ (Appendix). In terms of the parental contribution to heterosis according to stem length, the Şanlıurfa Mrkz parents' value (19.64\%) was the highest, Bozova Mrkz parents' value $(-1.19 \%)$ was the lowest (Table 3). When yield value, which is one of the most important traits when developing a cultivar, is examined, it was concluded that the differences between parents and hybrids are much more distinctive. When parents and hybrids were examined for yield, the average was $1876.02 \mathrm{~kg}$ for the hybrids, and was $1636.25 \mathrm{~kg}$ for the parents. The highest yield for the parents belonged to the Sanliurfa Mrkz. (2600 kg), and to a hybrid obtained from Konak $\mathrm{x}$ Şanlıurfa Mrkz (7x8) (3233.41 kg) (Appendix). When heterosis values were analyses for yield, the Bozova Mrkz x Şanlıurfa Mrkz (5x8) hybrid had the highest heterosis value $(32,67 \%)$, whereas the lowest heterosis $(-13,17 \%)$ was observed from the Halfeti-1 x Bozova Mrkz (3x5) hybrid (Appendix). The highest heterobeltiosis value $(24.36 \%)$ was obtained from the Konak x Şanliurfa Mrkz hybrid, and the lowest (-67.20\%) was from the Tutluca-1 x Tutluca-2 hybrid (Appendix). When the contribution of the parents to heterosis and heterobeltiosis were examined, the highest contribution $(27.15 \%$ and $0.18 \%$, respectively) was obtained from Şanliurfa Mrkz parent, and the lowest values were from Halfeti-1 $(5.25 \%)$ and Tutluca-1 (-44.86\%) parents (Table 3 and Table 5).

For all the traits analyzed for heterosis in this study, the best results were observed from Şanliurfa Mrkz genotype, except 50\% flowering time, in which this parent was ranked last (Table 3). When the data was examined for the average of the hybrids, the Halfeti-1 x Şanlıurfa Mrkz (3x8) hybrid was recorded as having the highest values for plant length, stem diameter and plant width-spread traits, this hybrid had the lowest value for only 50\% flowering time (Appendix). Tutluca$1 \mathrm{x}$ Tutluca-2 (1x2) hybrid had the highest value for the leaf number (number/plant). While Tutluca-1 x Yaslica (1x6) hybrid average was the highest for stem length (cm), and the Konak x Şanliurfa Mrkz (7x8) hybrid had the highest yield average in their group. When the heterosis values were analyzed for all traits, it was concluded that heterotic influence was quite effective and for each trait, different hybrids presented their heterotic differences with varied values (Appendix, Tables 3-4).

Table 3. Contribution of parents to heterosis for the analyzed traits

\begin{tabular}{c|c|c|c|c|c|c|c}
\hline & $\begin{array}{c}\text { Plant } \\
\text { length } \\
\text { (cm) }\end{array}$ & $\begin{array}{c}\text { Stem } \\
\text { diameter } \\
(\mathbf{m m})\end{array}$ & $\begin{array}{c}\text { Plant } \\
\text { width- } \\
\text { spread } \\
\text { (cm) }\end{array}$ & $\begin{array}{c}\text { Number } \\
\text { of leaves } \\
\text { (number) }\end{array}$ & $\begin{array}{c}\mathbf{5 0 \%} \\
\text { Female } \\
\text { flowering } \\
\text { time (day) }\end{array}$ & $\begin{array}{c}\text { Stem } \\
\text { length } \\
\text { (cm) }\end{array}$ & $\begin{array}{c}\text { Yield } \\
\text { (Kg/Da) }\end{array}$ \\
\hline Tutluca1 & 1.78 & 2.63 & 3.01 & 6.53 & 2.17 & 8.24 & 8.15 \\
Tutluca2 & 3.01 & 1.64 & 1.73 & 2.98 & 3.49 & 1.04 & 12.35 \\
Halfeti1 & 4.07 & 3.14 & 2.23 & 6.24 & 3.13 & 3.31 & 5.25 \\
Halfeti2 & 3.96 & 2.73 & -1.11 & 5.42 & 5.28 & 7.48 & 9.36 \\
Bozova Mr & 2.56 & 5.61 & 2.61 & 4.09 & 0.54 & -1.19 & 8.76 \\
Yaslica & 3.98 & 2.24 & -0.67 & 2.71 & 3.55 & 8.41 & 12.49 \\
Konak & 0.46 & 2.10 & 1.36 & 6.42 & 1.43 & 12.31 & 21.15 \\
Şanliurfa Mr & 6.52 & 4.08 & 12.43 & 10.44 & -4.90 & 19.64 & 27.15 \\
Average & 3.29 & 3.02 & 2.70 & 5.60 & 1.84 & 7.41 & 13.08 \\
\hline
\end{tabular}


Table 4. Contribution of parents to heterobeltiosis for the traits evaluated

\begin{tabular}{c|c|c|c|c|c|c|c}
\hline & $\begin{array}{c}\text { Plant } \\
\text { length } \\
(\mathbf{c m})\end{array}$ & $\begin{array}{c}\text { Stem } \\
\text { diameter } \\
(\mathbf{m m})\end{array}$ & $\begin{array}{c}\text { Plant } \\
\text { width- } \\
\text { spread } \\
(\mathbf{c m})\end{array}$ & $\begin{array}{c}\text { Number } \\
\text { of leaves } \\
\text { (number) }\end{array}$ & $\begin{array}{c}\mathbf{5 0 \%} \\
\text { Female } \\
\text { flowering } \\
\text { time (day) }\end{array}$ & $\begin{array}{c}\text { Stem } \\
\text { length } \\
\text { (cm) }\end{array}$ & $\begin{array}{c}\text { Yield } \\
\text { (kg/da) }\end{array}$ \\
\hline Tutluca1 & -27.54 & -13.07 & -24.42 & -27.81 & -14.47 & -4.99 & -44.86 \\
Tutluca2 & -23.35 & -14.67 & -25.89 & -31.53 & -10.63 & -8.48 & -42.10 \\
Halfeti1 & -16.32 & -6.31 & -15.11 & -25.60 & -25.60 & -12.37 & -19.85 \\
Halfeti2 & -19.19 & -8.16 & -22.85 & -29.15 & -26.59 & -9.41 & -22.89 \\
Bozova Mr & -34.91 & -16.93 & -26.40 & -31.81 & -22.72 & -7.91 & -44.34 \\
Yaslica & -32.54 & -24.17 & -25.03 & -30.79 & -28.31 & -3.26 & -41.42 \\
Konak & -18.40 & -11.48 & -19.33 & -20.26 & -20.96 & 1.77 & -7.48 \\
Şanliurfa Mr & -13.26 & -9.73 & -2.08 & -8.28 & -29.02 & 2.01 & 0.18 \\
Average & -23.19 & -13.07 & -20.14 & -25.66 & -22.29 & -5.33 & -27.85 \\
\hline
\end{tabular}

The hybrids range in a wide interval in terms of their heterosis values (Appendix). When the data was examined, the hybrids had a plant length average between -3.98 (1x7) and $9.6(5 \times 8)$, stem diameter average between $-4.51(3 \times 6)$ and $9.13(4 \times 5)$, plant width-spread values between $-8.03(3 \times 4)$ and $16.18(2 \times 8)$, leaf number averages between $-7.05(3 \times 6)$ and $19.13(7 \times 8), 50 \%$ female flowering time averages between $21.25(3 \times 8)$ and $19.21(1 \times 3)$, stem length averages between $-22.62(3 \times 4)$ and $26.78 \mathrm{~cm}$ $(4 \times 8)$, and yield average values between $-13.17(3 \times 5)$ and $32.67(5 \times 8)$. These values were caused by the heterotic differences between the parents used in this study.

A high statistical significance of $1 \%$ among all the traits except stem diameter was obtained (Appendix). The error mean squares of the analyzed traits were significant and it highlights the existence of a wide variation among the materials tested (Table 5).

Table 5. Error mean square values of variance analyze and analyzed characteristics

\begin{tabular}{c|c|c|c|c|c|c|c}
\hline S.V. & $\begin{array}{c}\text { Plant } \\
\text { length } \\
(\mathbf{c m})\end{array}$ & $\begin{array}{c}\text { Stem } \\
\text { diameter } \\
(\mathbf{m m})\end{array}$ & $\begin{array}{c}\text { Plant } \\
\text { width- } \\
\text { spread } \\
(\mathbf{c m})\end{array}$ & $\begin{array}{c}\text { Number } \\
\text { of leaves } \\
(\text { number })\end{array}$ & $\begin{array}{c}\mathbf{5 0 \%} \\
\text { Female } \\
\text { flowering } \\
\text { time } \\
(\mathbf{d a y})\end{array}$ & $\begin{array}{c}\text { Stem } \\
\text { length } \\
(\mathbf{c m})\end{array}$ & $\begin{array}{c}\text { Yield } \\
(\mathbf{K g} / \mathbf{D a})\end{array}$ \\
\hline $\mathrm{F}$ & $3.09^{* *}$ & $2.46^{\mathrm{NS}}$ & $18.32^{* *}$ & $11.18^{* *}$ & $2.90^{* *}$ & $59.07^{* *}$ & $30.20^{* *}$ \\
Variety & $79.04^{* *}$ & 17.52 & $1478.67 * *$ & $287.61^{* *}$ & $91.50^{* *}$ & $2769863^{* *}$ & $1460006^{* *}$ \\
\hline
\end{tabular}

** $1 \%$ statistical significance exists.

When heterosis and heterobeltiosis values for yield traits were analyzed according to phylogenetic tree (Fig. 2), the Bozova Mrkz and Şanliurfa Mrkz parents, which composed the Bozova Mrkz x Şanliurfa Mrkz hybrid with the highest heterosis value are the members of two different groups; while the parents of the hybrid with the lowest heterosis value (Halfeti1 x Bozova Mrkz) belongs to same group of parents, and similarities between them are closer to each other. It was determined that the hybrids composed of the individuals that are phylogenetically farther from each other had higher yield values. Konak x Şanliurfa Mrkz, which had the highest heterobeltiosis values, belonged to different groups, while the Tutluca1 x Tutluca2 hybrid had the lowest value, were the farthest members in the phylogenetic tree, but genetically, the fruits of 
both parents were small, and their contribution to the heterobeltiosis value was not sufficient.

When the literature was searched concerning our topic, it was seen that there are very few studies with regards to determining the heterotic characteristics in summer squash. Helmy (1993) identified the highest positive heterosis contribution for total fruit number and fruit weight per plant by evaluating 15 hybrids and parents in his study with six inbred agoor lines (Cucumis melo var. chata, L.) El-Adl et al. (1996) reported parallel results with our study by identifying a positive influence of heterosis contribution on yield. Pradip et al. (2013) conducted a study on the yield and antioxidant contents of 28 Luffa acutangula (Roxb.) L. genotypes (7 of them were parents), and reported that genetic variability was quite effective on heterosis and on general and specific combining abilities, similar to our study. Iathet and Piluek (2006) reported that the number of fruit and yield per plant in melons had high heterosis values $(0.61$ and 0.60 , respectively) due to genetic differences; and they found high correlation between number of fruits and yield per plant. It was found by López-Sesé and Staub (2002) that the effect of combining ability on yield and its components continued for many years. According to Feyzian et al. (2009) while dominant genes are effective on high yield, the effect of new genes obtained by hybridization on the average weight of fruit was quite high too. The transfer of superior genes by hybridization (addition) increases starch content and especially seed production (in pumpkin) by repeated hybridization reported by Sanin et al. (2014) recently. The effect of agglutinative and non-agglutinative genes against the resistance to parthenocarpy and water melon mosaic virus was significant in summer squash (Douglas et al., 2011). In a study conducted with 28 Luffa acutangula (Roxb.) L. genotypes, very high level of genetic variation was found; the general and specific combining ability values were quite important for yield and antioxidants (ascorbic acid, total carotenoid and total phenolics), and a high mean square value for the parents and hybrids were reported (Pradip et al., 2013). Pradip et al.'s study (2013) shows similarities to our study regarding square means. In the melon study by Iathet and Piluek (2006), it was determined that number of fruit per plant and plant productivity/yield was highly genetic, and there was a high and positive correlation between the number of fruit per plant and plant yield. In a study with cucumber in the gourd family, it was recorded that the number of fruit per plant and plant yield was mostly under genetic control, while with the maximum genetic difference, the plant yield increases when number of fruit per plant increases (Mishra et al., 2007). Gabr (2003) and Abd El-Hadi et al. (2004) who worked on heterosis and economic implementations in squash, and Abdein (2005), Al-Ballat (2008) and Al-Araby (2010), found significant effects of heterosis on squash, as in our study. Thangamani et al. (2011), who conducted heterosis studies on 10 parents and diallel hybrids, reported that heterosis in squash had a positive effect on yield and quality. The study conducted by Jahan et al. (2012) determined a desired positive effect of heterosis on the number of fruit per plant and yield of pumpkins (Cucurbita moschata Duch. ex Poir). Marie et al. (2012), who reached results parallel to our study, found that heterosis had a high effect on yield, yield components and female flowering time.

In order to find the genetic similarities of eight domestic summer squash genotypes used in the study (Tutluca 1, Tutluca 2, Halfeti 1, Halfeti 2, Bozova Mrkz., Yaslica, Konak and Şanlıurfa Mrkz.), a nucleotid series of the trnL-F region of chloroplast genome, which is widely used in genetic relationship studies in plants, is used. The alignment process, which is the most important of the processes carried out to determine 
the relationships between genotypes, was run through ClustalX 2.0, and results given in Fig. 1. When we look at the result of alignment, a sufficient polymorphism was seen between genotypes.

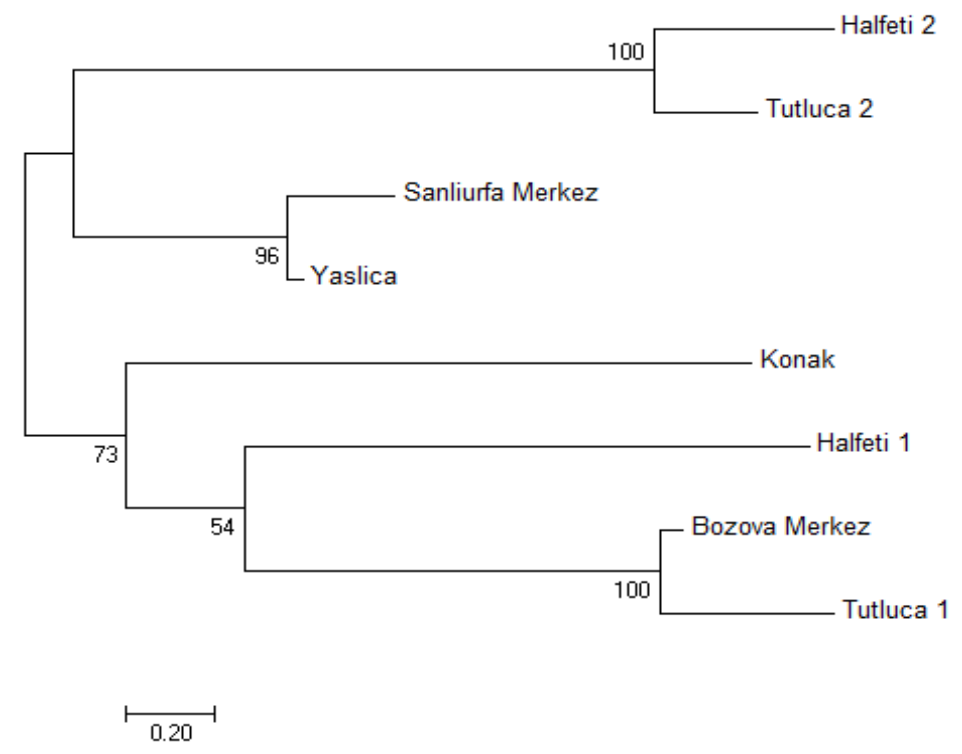

Figure 1. The determination of the genetic relationships of the parent genotypes with the Neighbor-Joining (NJ) method (numbers on branch demonstrate the bootstrap values)

The phylogenetic tree which was obtained with MEGA 7 (Yadav et al., 2015) software to find genetic relationships between parents was shown in Fig. 2. By using 500 bootstrap recurrences of the series of chloroplast $t r n \mathrm{~L}-\mathrm{F}$ region, the parents were observed to be divided into two main groups (Fig. 2). Halfeti2, Tutluca2, Şanluurfa Merkez and Yaslica genotypes took part in the first group. In this group, while Halfeti2 showed a close relationship with Tutluca2 with a high bootstrap value, Şanliurfa Mrkz was also observed with almost the same level of bootstrap value and showed close relationship with the Yaslica genotype. On the other hand, Konak, Halfeti1, Bozova Merkez, Tutlucal genotypes took place in the second group. In this group, while Konak and Halfeti1 genotypes presented a polyphyletic situation, with a quite high bootstrap value, the Bozova Merkez and Tutlucal genotypes were in close genetic relation and showed a monophyletic situation (Fig. 2).

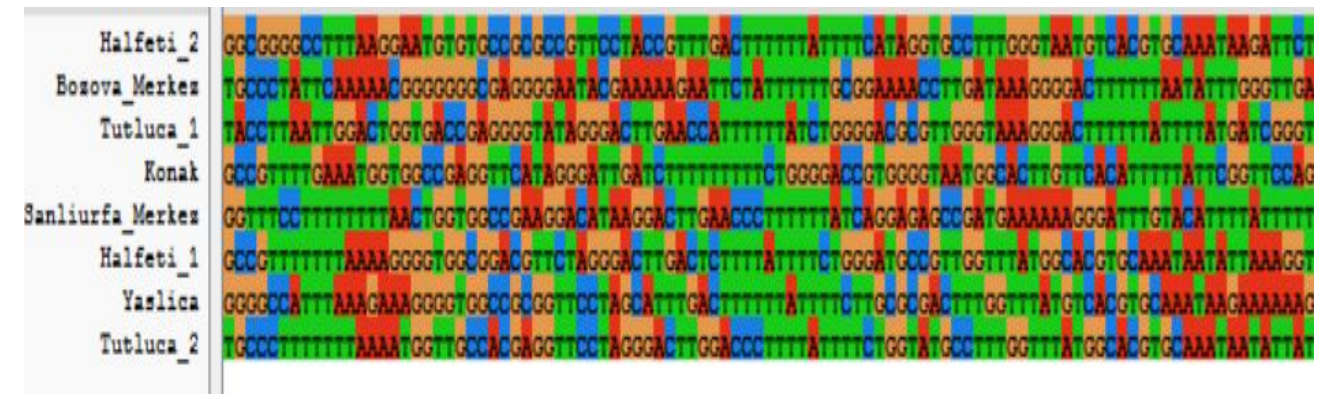

Figure 2. A section of the series aligned with Clustal X 2.0 of parent genotypes 
To estimate the evolutionary distance between the trnL-F series to determine the genetic relation between parents, the Maximum Composite Likelihood model combined with MEGA 7.0 software was used (Tamura et al., 2007) (Fig. 3). Composite likelihood algorithm provides accurate substitution parameters and can use the pairwise distances of sequences in a distance matrix that have connection with phylogenetic relationships among the sequences (Fig. 1). So, our result, in which base change models between series was considered, supports the topology of the phylogenetic tree in Fig. 1.

\begin{tabular}{l|llllllll|} 
& 1 & 2 & 3 & 4 & 5 & 6 & 7 & 8 \\
\hline 1. Halfeti 2 & & 0.51 & 0.58 & 0.65 & 0.42 & 0.62 & 0.46 & 0.06 \\
\hline 2. Bozova Merkez & 2.74 & & 0.04 & 0.49 & 0.37 & 0.52 & 0.46 & 0.62 \\
\hline 3. Tutluca 1 & 3.33 & 0.44 & & 0.48 & 0.57 & 0.43 & 0.61 & 0.61 \\
4. Konak & 3.73 & 2.75 & 2.65 & & 0.46 & 0.57 & 0.35 & 0.55 \\
5. Sanliurfa Merkez & 2.40 & 2.16 & 2.89 & 2.56 & & 0.45 & 0.03 & 0.32 \\
6. Halfeti 1 & 3.59 & 2.49 & 2.33 & 3.03 & 2.57 & & 0.31 & 0.63 \\
7. Yaslica & 2.65 & 2.45 & 3.15 & 2.03 & 0.27 & 1.89 & & 0.32 \\
8. Tutluca 2 & 0.63 & 3.32 & 3.74 & 3.06 & 1.94 & 3.42 & 1.92 &
\end{tabular}

Figure 3. The estimation of evolutionary distance between parents

In conclusion, as a result of this study, in which eight parents and 28 hybrids (obtained from these parents without reciprocals) were used as materials, the heterotic effects of summer squash for yield and some agronomic traits were evaluated. The highest heterotic effects occurred in the summer squash yield characteristic. A maximum of $32.67 \%$ heterosis and $24.36 \%$ heterobeltiosis values were observed. With these results, it was concluded that the $5 \times 8$ (Bozova Mrkz x Şanlıurfa Mrkz) and the 4 x 8 (Halfeti-2 x Şanliurfa Mrkz) hybrids are likely to be the most promising hybrid combinations for the traits analyzed, when we evaluated the parents according to their contribution to heterosis and heterobeltiosis. It was seen that the highest contribution in the summer squash yield was obtained from the Şanliurfa Mrkz parent and followed by Konak and Yaslica parents, respectively. Chloroplast DNA based phylogenetic relationships of parents supported that obtained values of heterosis and heterobeltiosis are permanent and not coincidental.

Acknowledgements. The research was financed by The GAP (Southeast Anatolia Project) Agriculture Research Institute in Sanliurfa.

\section{REFERENCES}

[1] Abd El-Hadi, A. H., Zaghloul, M. M., Gabr, A. H. (2004): Nature of gene action, heterosis and inbreeding depression of yield and yield component traits in squash (Cucurbita pepo, L.). - Zagazig J. Agric, Res. 31 (6): 2707-2725.

[2] Abdein, M. A. (2005): Quantitative genetics of some economic traits in squash (Cucurbita pepo L.). [MSc. Thesis.] - Fac. of Agric., Mansoura Univ. Egypt.

[3] Ahmad, S., Muhammad, S. K., Muhammad, S. S., Gul, S. S., Iftıkhar, H. K. (2005): A Study on Heterosis and Inbreeding Depression in Sunflower (Helianthus annuus L.). Songklanakarin J. Sci. Technol. 27 (1): 1-8. 
[4] Al-Araby, A. A. (2010): Estimation of heterosis, combining ability and heritability in inter varietals crosses of summer squash (Cucurbita pepo L.). [PhD. Thesis.] - Fac. of Agric. Tanta Univ. Egypt.

[5] Al-Ballat, I. A. (2008): Breeding studies on summer squash crop (Cucurbita pepo L.). [MSc. Thesis.] - Fac. of Agric., Tanta Univ. Egypt.

[6] Almaca, A., Gok, M. (1997): Değişik Bradyrhizobium japonicum izolatları ile aşılamanın farklı soya çeşitlerinde GAP bölgesinde (Harran Ovası) nodulasyon, $\mathrm{N}_{2}$-fiksasyonu ve verime etkisi. - In: Proc. 1st Trakya Toprak ve Gübre Sempozyumu. Oct 20-22, 1997. 213-220.

[7] Anonymous (2012): GAP Agricultural research Institute-Sanliurfa.

[8] Anonymous (2013): FAO statistical database. [Online] Available: http://www.fao.org

[9] Cho, Y., Park, C. W., Kwon, S. W., Chin, J. H., Ji, H. S., Park, K. .J. (2004): Key DNA Markers for Predicting Heterosis in F1 Hybrids of Japonice Rice. - Breeding Science 54: 389-397.

[10] Curtis, L. C. (1939): Heterosis in summer squash (Cucurbita pepo) and the possibilities of producing F1 hybrid seed for commercial planting. - Proc. Amer. Soc. Hort. Sci. 37: 827-828.

[11] Curtis, L. C. (1941): Comparative earliness and productivenss of first and second generation Summer Squash (C. pepo) and the possibilities of using the second generation seed for commercial planting. - Proc Am Soc Hortic Science 38: 596-598.

[12] Denizer, B., San, A., Boyaci, H. F., Işik, E. A. (2005): Patlıcanda (Solanum melongenae L.) Verim ve Verim Bileşenlerinde Heterosis Oranları. - Proc. Türkiye II. Tohumculuk Kongresi, Nov 9-11, 2005: 113-119.

[13] Dinc, U., Senol, S., Sayın, M., Kapur, S., Guzel, N., Derici R., Kara H. (1988): Güneydoğu Anadolu Toprakları (GAP), I. Harran Ovası - TÜBİTAK, TOAG 534 nolu Kesin Sonuç Raporu

[14] Douglas, W. N., Maluf, W. R., Figueira, A. R., Maciel, G. M., Gomes, L. A., Benavente, C. A. (2011): Combining ability of summer-squash lines with different degrees of parthenocarpy and PRSV-W resistance. - Genetics and Molecular Biology 34 (4): 616623.

[15] D. S. I. (1980): Guneydogu Anadolu projesi. - Devlet Su Isleri Genel Mudurlugu Ankara

[16] El-Adl, A. M., Kosba, Z. A., El-Diasty, Z. M., Abd El-Hadi, A. H. (1996): Types of gene action associated with the performances of hybrids among newly developed inbred lines of agoor, (Cucumis melo var. chate, L.). - J. Agric. Sci. Mansoura Univ. 21 (8): 28212835 .

[17] Elmstrom, G. W. (1978): Evaluation of summer squash varieties for Florida. - Proc Fl. State Hortic. Soc. 91: 321-324.

[18] Falconer, D. S., Mackay, T. F. C. (1996): Introduction to Quantitative Genetics (fourth ed). - Longman, Harlow, England.

[19] Feyzian, E., Dehghani, H., Rezai, A. M., Javaran, M. J. (2009): Diallel cross analysis for maturity and yield related traits in melon (Cucumis melo L.) - Euphytica 168 (7): 215223.

[20] Fonseca, S., Paterson, F. L. (1968): Hybrid vigor in a seven parent diallel cross in common winter wheat (Triticum aestivum L.) - Crop Sci., 8: 85-88.

[21] Gabr, A. H. (2003): Nature of gene action and performance of hybrids in squash (Cucurbita pepo, L.). [MSc. Thesis.] - Fac. of Agric., Mansoura Univ. Egypt.

[22] Hallauer, A. R., Miranda Filho, J. B. (1988): Quantitative Genetics in Maize Breeding. (2nd edn). - Iowa State University Press, Ames.

[23] Harrison, K. M. (2002): World trends driving horticulture expansion in emerging economies. - Acta Hort. 621: 115-125.

[24] Helmy, E. M. S. (1993): Development of pure lines of summer squash and their use in hybrid production. - J. Agric. Sci., Mansoura Univ. 18 (2): 489-498. 
[25] Iathet, C., Piluek, K. (2006): Heritability, heterosis and correlations of fruit characters and yield in Thai slicing melon (Cucumis melo L. var. conomon makino). Kasetsart Journal (Natural Sciences) 40 (6): 20-25.

[26] Jahan, T. A., Islam, A. K. M., Rasul, M. G., Mian, M. A. K., Haque, M. M. (2012): Heterosis of qualitative and quantitative characters in sweet gourd (Cucurbita moschata Duch. ex Poir). - African Journal of Food, Agriculture, Nutrition and Development 12 (3): 6186- 6199.

[27] Jose, M. A., Iban, E., S1lvia, A., Pere, A. (2005): Inheritance Mode of Fruit Traits in Melon: Heterosis for Fruit Shape and its Correlation with Genetic Distance. - Euphytica 144 (1/2): 31-38.

[28] Karaca, M., Ince, A. G, Elmasulu, S. Y., Onus A.N., Turgut K. (2005): Coisolation of genomic and organelle DNAs from 15 genera and 31 species of plants. - Anal. Biochem . 343: 353-355.

[29] Karipcin, M. Z., Sarı, N., (2012): Effect of $\mathrm{NaCl}$ application on physiological, morphological and pomological features of Sanliurfa summer squash genotypes. Cucurbitaceae. - Proceedings of the Xth EUCARPIA Meeting on Genetics and Breeding of Cucurbitaceae, Antalya-Turkey. 702-706.

[30] López-Sesé, A. I., Staub, J. (2002): Combining ability analysis of yield components in cucumber. - Journal of the American Society for Horticultural Science 127 (6): 931-937.

[31] Marie, A. K., Moualla, M. Y., Boras, M. G. (2012): Heterosis study of some quantity characters of squash (Cucurbita pepo, L.). - Damascus J. of Agric. Sci. 28 (1):339-354.

[32] Melchinger, A.E. (1999): In The genetics and exploitation of heterosis in crops, Genetic diversity and heterosis, eds; Coors, J.G., Pandey, S. (Crop Science Society of America, Madison, WI). 99-118.

[33] Mishra, G., Yadav, J. R., Parihar, N. S., Yadav, J. K., Kumar, S., Alok, Y. (2007): Study on heritability and genetic advance in cucumber (Cucumis sativus, L.). - Progressive Research 2 (3):187-189.

[34] Moll, R., Salhuana, W. S., Robinson, H. F. (1962): Heterosis and genetic diversity in variety crosses of maize. - Crop science 2 (3): 197-198.

[35] Moll, R. H., Lonnquist, J. H., Fortuno, J. V., Johnson, E. C. (1965): The relationship of heterosis and genetic divergence in maize. - Genetics 52 (1): 139.

[36] Paris, H. S. (1986): A proposed subspecific classification for Cucurbita pepo. Phytologia 61: 133-138.

[37] Paris, H. S. (2008): Summer squash. In: Prohens J, Nuez F (eds) Handbook of plant breeding, Vegetables I. Springer, New York. 351-379

[38] Pearson, O. H. (1983): Heterosis in vegetable crops. In: R. Frankel (Ed.). Heterosis. Reappraisal of Theory and Practice. Springer-Verlag, Berlin. 138-188.

[39] Pradip, K., Munshi, A. D., Behera, T. K., Kumar, R., Kaur, C., Singh, B. K. (2013): Hermaphrodite inbreds with better combining ability improve antioxidant properties in ridge gourd [Luffa acutangula (Roxb.) L.] - Euphytica 191 (3):75-84.

[40] Saitou, N., Ǵmanishi, T. (1989): Relative efficienciens of the Ficth-Margoliash, Maximum Parsinomy, Maximum-Likelihood, Minimum-Evolution and NeighbourJoining methods of phylogenetic tree construction in obtaining the correct tree. - Mol Biol Evol. 6: 514-525.

[41] Sanin, O. G., Burbano, L. V. B., Narvaez, G. A. O., Restrepo, M. P. V, Garcia, D. B., Cabrera, F. A. V. (2014): Inbreeding and gene action in butternut squash (Cucurbita moschata) seed starch content. - Rev. Fac. Nal. Agr. Medellin 67 (1): 7169-7175.

[42] Sari, N., Yetişir, H., Ekbiç, E., Gök, P. (2003a): Kavunlarda Bitki Boyu ve Gövde Çap1 Üzerine Heterozis Etkisi.- IV. Sebze Tarımı Sempozyumu Bildiri Kitabı, 17-20 Eylül 2002, Uludağ Üniv Basımevi, Bursa. 1-10.

[43] Sari, N., Yetişir, H., Ekiz, H., Ekbiç, E., Yücel, S. (2003b): Kavunda Fusarium Solgunluğuna Dayanıklı F1 Hibrit Çeşit Islahı. DPT Araştırma Projesi Sonuç Raporu. 
[44] Skreden, M., Bere, E., Sagedal, L. R., Vistad, I., Øverby, N. C. (2017). Changes in fruit and vegetable consumption habits from pre-pregnancy to early pregnancy among Norwegian women. - BMC pregnancy and childbirth 17 (1): 107.

[45] Small, R. L., Cronn, R. C., Wendell, J. F. (2004): Use of nuclear genes for phylogeny reconsruction in plants. - Australian Systematic Botany 17: 145-170.

[46] Stuber, C. W. (1994): Heterosis in plant breeding. - Plant Breed Rev. 12: 227-251.

[47] Taberlet, P., Gielly, L., Pautou, G., Bouvet, J. (1991): Universal primers for amplification of three non-coding regions of chloroplast DNA. - Plant molecular biology 17 (5): 11051109.

[48] Tamura, K., Dudley, J., Nei, M., Kumar, S. (2007): MEGA4: molecular evolutionary genetics analysis (MEGA) software version 4.0. - Molecular biology and evolution 24 (8): 1596-1599.

[49] Thangamani, C., Pugalendhi, L., Sumathi, T., Kavitha, C., Rajashree, V. (2011): Estimation of combining ability and heterosis for yield and quality characters in bitter gourd (Momordica charantia L.). - Electronic Journal of Plant Breeding 2 (1): 62-66

[50] Virmani, S. S., Sun, Z. X., Mou, T. M., Jauhar Ali, A., Mao, C. X. (2003): Two-Line Hybrid Rice Breeding Manual. - Los Baños (Philippines), International Rice Research Institute. 88.

[51] Turkstat (2015): Türkiye İstatistik Kurumu resmi web sitesi. Available at www.tuik.gov.tr

[52] Yadav, A. N., Verma, P., Kumar, M., Pal, K. K., Dey, R., Gupta, A., Prasanna, R. (2015): Diversity and phylogenetic profiling of niche-specific Bacilli from extreme environments of India. - Annals of Microbiology 65 (2): 611-629.

[53] Yu, S. B., Li, J. X., Xu, C. G., Tan, Y. F., Gao, Y. J., Li, X. H., Maroof, M. S. (1997): Importance of epistasis as the genetic basis of heterosis in an elite rice hybrid. Proceedings of the National Academy of Sciences 94 (17): 9226-9231.

\section{APPENDIX}

Chart 1. Average values of parents and F1 hybrids in terms of the analyzed characteristics

\begin{tabular}{l|c|c|c|c|c|c|c}
\hline Parents & $\begin{array}{c}\text { Plant } \\
\text { length } \\
\text { (cm) }\end{array}$ & $\begin{array}{c}\text { Stem } \\
\text { diameter } \\
(\mathbf{m m})\end{array}$ & $\begin{array}{c}\text { Plant } \\
\text { width- } \\
\text { spread } \\
\text { (cm) }\end{array}$ & $\begin{array}{c}\text { Leaf } \\
\text { number } \\
\text { (number) }\end{array}$ & $\begin{array}{c}\text { 50\% } \\
\text { Female } \\
\text { flowering } \\
\text { time } \\
\text { (day) }\end{array}$ & $\begin{array}{c}\text { Stem } \\
\text { length } \\
\text { (cm) }\end{array}$ & $\begin{array}{c}\text { Productivity } \\
\text { (kg/da) }\end{array}$ \\
\hline 1. Tutluca1 & 25.4 & 19.1 & 123.3 & 43.2 & 34.1 & 32.2 & 850 \\
2. Tutluca2 & 28.1 & 18.6 & 120.8 & 41.2 & 36.5 & 34.5 & 910 \\
3. Halfeti1 & 33.3 & 22.2 & 165.2 & 47.2 & 24.2 & 29.3 & 2380 \\
4. Halfeti2 & 31.1 & 21.5 & 143.6 & 42.3 & 22.4 & 28.9 & 2080 \\
5. Bozova & 18.2 & 15.8 & 116.5 & 39.8 & 28.5 & 36.7 & 900 \\
Mr & 23.5 & 16.2 & 132.6 & 42.4 & 21.9 & 33.3 & 930 \\
6. Yaslica & 23.2 & 20.1 & 150.4 & 54.3 & 29.1 & 34.6 & 2440 \\
$\begin{array}{c}\text { 7. Konak } \\
\text { 8. Sanlıurfa }\end{array}$ & 34.5 & 22.8 & 183.2 & 67.3 & 26.2 & 29.9 & 2600 \\
Mrkz. & 38.2 & & & & \\
\hline
\end{tabular}




\section{Hybrids}

\begin{tabular}{|c|c|c|c|c|c|c|c|}
\hline $1 \times 2$ & 26.57 & 18.68 & 117.52 & 39.83 & 36.26 & 30.67 & 852.90 \\
\hline $1 \times 3$ & 30.17 & 21.36 & 152.15 & 51.15 & 34.75 & 31.80 & 1713.03 \\
\hline $1 \times 4$ & 30.06 & 19.74 & 132.96 & 46.97 & 28.16 & 37.66 & 1549.24 \\
\hline $1 \times 5$ & 23.09 & 19.01 & 123.98 & 43.19 & 29.40 & 29.91 & 883.84 \\
\hline $1 \times 6$ & 25.25 & 19.25 & 123.45 & 46.49 & 24.91 & 40.99 & 914.65 \\
\hline $1 \times 7$ & 28.61 & 19.26 & 147.36 & 50.11 & 33.49 & 36.01 & 1995.06 \\
\hline $1 \times 8$ & 31.53 & 21.43 & 171.84 & 62.33 & 31.57 & 37.02 & 2126.24 \\
\hline $2 \times 3$ & 32.97 & 20.22 & 150.69 & 45.71 & 31.46 & 31.65 & 1767.88 \\
\hline $2 \times 4$ & 30.12 & 19.33 & 129.08 & 39.21 & 30.80 & 33.84 & 1550.46 \\
\hline $2 \times 5$ & 23.68 & 17.99 & 114.20 & 42.08 & 31.52 & 30.04 & 1067.63 \\
\hline $2 \times 6$ & 27.76 & 16.87 & 133.63 & 45.57 & 33.00 & 35.96 & 1022.12 \\
\hline $2 \times 7$ & 29.31 & 21.01 & 128.71 & 52.61 & 34.28 & 36.18 & 2047.35 \\
\hline $2 \times 8$ & 36.16 & 22.09 & 176.59 & 57.53 & 31.03 & 36.77 & 2229.38 \\
\hline $3 \times 4$ & 33.29 & 23.14 & 142.00 & 52.18 & 26.49 & 22.52 & 1945.45 \\
\hline $3 \times 5$ & 24.77 & 19.74 & 142.88 & 49.07 & 27.25 & 31.81 & 1424.01 \\
\hline $3 \times 6$ & 29.62 & 18.33 & 143.27 & 41.64 & 24.67 & 33.41 & 1700.68 \\
\hline $3 \times 7$ & 35.94 & 22.78 & 164.19 & 50.26 & 25.63 & 39.24 & 2928.63 \\
\hline $3 \times 8$ & 38.74 & 23.96 & 193.50 & 60.50 & 19.85 & 34.70 & 3108.27 \\
\hline $4 \times 5$ & 25.61 & 20.35 & 134.29 & 41.88 & 26.74 & 33.93 & 1520.25 \\
\hline $4 \times 6$ & 28.47 & 19.51 & 127.29 & 42.08 & 24.84 & 32.88 & 1838.81 \\
\hline $4 \times 7$ & 32.37 & 20.60 & 138.08 & 52.08 & 26.46 & 34.62 & 2652.34 \\
\hline $4 \times 8$ & 37.86 & 23.90 & 185.67 & 59.37 & 24.07 & 37.27 & 2977.65 \\
\hline $5 \times 6$ & 20.29 & 16.77 & 120.70 & 38.59 & 26.04 & 32.57 & 939.80 \\
\hline $5 \times 7$ & 26.92 & 18.64 & 141.48 & 51.20 & 30.20 & 38.46 & 1972.77 \\
\hline $5 \times 8$ & 31.07 & 20.07 & 166.30 & 55.20 & 26.30 & 39.87 & 2321.73 \\
\hline $6 \times 7$ & 29.39 & 18.33 & 133.00 & 46.96 & 26.53 & 36.61 & 2008.69 \\
\hline $6 \times 8$ & 21.02 & 11.95 & 180.10 & 64.70 & 23.17 & 36.10 & 2236.43 \\
\hline $7 \times 8$ & 37.38 & 20.66 & 181.75 & 72.43 & 25.36 & 40.33 & 3233.41 \\
\hline
\end{tabular}




\begin{tabular}{c|c|c|c|c|c|c|c}
$\mathbf{C V}(\boldsymbol{\%})$ & 17.5 & 13.5 & 6.3 & 15.3 & 15.6 & 15.1 & 12.3 \\
\hline $\mathbf{F}$ & $3.09 * *$ & $2.46^{\mathrm{NS}}$ & $18.32 * *$ & $11.18^{* *}$ & $2.90 * *$ & $59.07 * *$ & $30.20 * *$ \\
\hline $\begin{array}{c}\text { Parents } \\
\text { Average }\end{array}$ & 29.04 & 19.54 & 141.95 & 47.21 & 27.86 & 32.43 & 1636.25 \\
\hline F1 Average & 29.57 & 19.82 & 146.31 & 50.03 & 28.37 & 34.74 & 1876.02 \\
\hline
\end{tabular}

$* * ; \mathrm{P}<0,01$

Chart 2. Heterocyst values of hybrids.

\begin{tabular}{|c|c|c|c|c|c|c|c|}
\hline & $\begin{array}{c}\text { Plant } \\
\text { length } \\
(\mathrm{cm})\end{array}$ & $\begin{array}{c}\text { Stem } \\
\text { diameter } \\
(\mathbf{m m})\end{array}$ & $\begin{array}{l}\text { Plant } \\
\text { width- } \\
\text { spread } \\
(\mathrm{cm})\end{array}$ & $\begin{array}{c}\text { Leaf number } \\
\text { (number) }\end{array}$ & $\begin{array}{c}50 \% \\
\text { Female } \\
\text { flowering } \\
\text { time } \\
\text { (day) }\end{array}$ & $\begin{array}{l}\text { Stem } \\
\text { length } \\
(\mathrm{cm})\end{array}$ & $\begin{array}{l}\text { Productivity } \\
\text { (kg/da) }\end{array}$ \\
\hline $1 \times 2$ & $\begin{array}{l}-0.67 \\
\end{array}$ & $\begin{array}{l}-0.88 \\
\end{array}$ & -3.71 & -5.61 & 2.71 & -8.03 & -3.08 \\
\hline $1 \times 3$ & 2.79 & 3.43 & 5.48 & 13.17 & 19.21 & 3.41 & 6.07 \\
\hline $1 \times 4$ & 6.40 & -2.74 & -0.37 & 9.86 & -0.31 & 23.28 & 5.75 \\
\hline $1 \times 5$ & 5.90 & 8.96 & 3.40 & 4.08 & -6.07 & -13.17 & 1.01 \\
\hline $1 \times 6$ & 3.29 & 9.07 & -3.52 & 8.63 & -11.04 & 25.17 & 2.77 \\
\hline $1 \times 7$ & -3.98 & -1.75 & 7.68 & 2.78 & 5.98 & 7.80 & 21.28 \\
\hline $1 \times 8$ & -1.30 & 2.30 & 12.13 & 12.82 & 4.71 & 19.24 & 23.26 \\
\hline $2 \times 3$ & 7.40 & -0.89 & 5.38 & 3.41 & 3.66 & -0.78 & 7.47 \\
\hline $2 \times 4$ & 1.76 & -3.59 & -2.36 & -6.09 & 4.58 & 6.75 & 3.71 \\
\hline $2 \times 5$ & 2.30 & 4.58 & -3.75 & 3.91 & -3.01 & -15.63 & 17.97 \\
\hline $2 \times 6$ & 7.60 & -3.03 & 5.47 & 9.03 & 13.03 & 6.07 & 11.10 \\
\hline $2 \times 7$ & -5.90 & 8.56 & -5.08 & 10.17 & 4.50 & 4.73 & 22.23 \\
\hline $2 \times 8$ & 8.60 & 6.73 & 16.18 & 6.05 & -1.02 & 14.19 & 27.03 \\
\hline $3 \times 4$ & 3.40 & 5.91 & -8.03 & 16.60 & 13.67 & -22.62 & -12.76 \\
\hline $3 \times 5$ & -3.80 & 3.87 & 1.44 & 12.81 & 3.40 & -3.60 & -13.17 \\
\hline $3 \times 6$ & 4.30 & -4.51 & -3.78 & -7.05 & 7.04 & 6.73 & 2.76 \\
\hline $3 \times 7$ & 6.50 & 7.69 & 4.05 & -0.96 & -3.84 & 22.83 & 21.52 \\
\hline $3 \times 8$ & 7.90 & 6.48 & 11.08 & 5.68 & -21.25 & 17.23 & 24.83 \\
\hline $4 \times 5$ & 3.90 & 9.13 & 3.26 & 2.02 & 5.08 & 3.43 & 2.03 \\
\hline
\end{tabular}




\begin{tabular}{c|c|c|c|c|c|c|c}
\hline $\mathbf{4 x 6}$ & 4.30 & 3.48 & -7.83 & -0.63 & 12.13 & 5.73 & 22.18 \\
$\mathbf{4 x 7}$ & -0.87 & -0.97 & -6.07 & 7.83 & 2.76 & 9.03 & 17.36 \\
$\mathbf{4 x 8}$ & 8.80 & 7.91 & 13.63 & 8.34 & -0.93 & 26.78 & 27.25 \\
$\mathbf{5 x 6}$ & -2.70 & 4.83 & -3.09 & -6.10 & 3.33 & -6.93 & 2.71 \\
$\mathbf{5 x 7}$ & 2.74 & 3.86 & 6.02 & 8.83 & 4.87 & 7.87 & 18.13 \\
$\mathbf{5 x 8}$ & 9.60 & 4.01 & 10.98 & 3.09 & -3.83 & 19.72 & 32.67 \\
$\mathbf{6 x 7}$ & 1.87 & 1.01 & -6.01 & -2.87 & 4.04 & 7.83 & 19.21 \\
$\mathbf{6 x 8}$ & 9.20 & 4.83 & 14.06 & 17.96 & -3.67 & 14.25 & 26.71 \\
$\mathbf{7 x 8}$ & 2.83 & -3.69 & 8.96 & 19.13 & -8.28 & 26.06 & 28.31 \\
\hline Average & 3.29 & 3.02 & 2.70 & 5.60 & 1.84 & 7.41 & 13.08 \\
\hline
\end{tabular}

Chart 3. Heterobeltiosis values of hybrids

\begin{tabular}{c|c|c|c|c|c|c|c}
\hline & $\begin{array}{c}\text { Plant } \\
\text { length } \\
\mathbf{( c m})\end{array}$ & $\begin{array}{c}\text { Stem } \\
\text { diameter } \\
(\mathbf{m m})\end{array}$ & $\begin{array}{c}\text { Plant } \\
\text { width- } \\
\text { spread } \\
\mathbf{( c m})\end{array}$ & $\begin{array}{c}\text { Leaf } \\
\text { number } \\
\text { (number) }\end{array}$ & $\begin{array}{c}\mathbf{5 0 \%} \\
\text { Female } \\
\text { flowering } \\
\text { time } \\
(\mathbf{d a y})\end{array}$ & $\begin{array}{c}\text { Stem } \\
\text { length } \\
(\mathbf{c m})\end{array}$ & $\begin{array}{c}\text { Productivity } \\
\text { (kg/da) }\end{array}$ \\
\hline $\mathbf{1 x 2}$ & -30.99 & -18.05 & -35.85 & -40.81 & -0.67 & -16.43 & -67.20 \\
$\mathbf{1 x 3}$ & -21.64 & -6.32 & -16.95 & -23.99 & -4.80 & -13.36 & -34.11 \\
$\mathbf{1 x 4}$ & -21.93 & -13.40 & -27.43 & -30.22 & -22.84 & 2.62 & -40.41 \\
$\mathbf{1 x 5}$ & -40.04 & -16.61 & -32.33 & -35.82 & -19.45 & -18.49 & -66.01 \\
$\mathbf{1 x 6}$ & -34.40 & -15.57 & -32.62 & -30.92 & -31.76 & 11.70 & -64.82 \\
$\mathbf{1 x 7}$ & -25.68 & -15.54 & -19.56 & -25.55 & -8.25 & -1.89 & -23.27 \\
$\mathbf{1 x 8}$ & -18.09 & -6.00 & -6.20 & -7.38 & -13.51 & 0.88 & -18.22 \\
$\mathbf{2 x 3}$ & -14.36 & -11.32 & -17.74 & -32.08 & -13.81 & -13.76 & -32.00 \\
$\mathbf{2 x 4}$ & -21.76 & -15.22 & -29.54 & -41.74 & -15.62 & -7.79 & -40.37 \\
$\mathbf{2 x 5}$ & -38.49 & -21.11 & -37.66 & -37.47 & -13.64 & -18.16 & -58.94 \\
$\mathbf{2 x 6}$ & -27.89 & -26.00 & -27.06 & -32.28 & -9.58 & -2.02 & -60.69 \\
$\mathbf{2 x 7}$ & -23.86 & -7.87 & -29.74 & -21.83 & -6.09 & -1.41 & -21.26 \\
$\mathbf{2 x 8}$ & -6.07 & -3.10 & -3.61 & -14.51 & -14.99 & 0.19 & -14.25 \\
$\mathbf{3 x 4}$ & -13.52 & 1.50 & -22.49 & -22.47 & -27.44 & -38.64 & -25.17 \\
\hline
\end{tabular}




\begin{tabular}{c|c|c|c|c|c|c|c}
\hline $\mathbf{3 x 5}$ & -35.66 & -13.44 & -22.01 & -27.08 & -25.35 & -13.32 & -45.23 \\
$\mathbf{3 x 6}$ & -23.06 & -19.59 & -21.79 & -38.13 & -32.40 & -8.97 & -34.59 \\
$\mathbf{3 x 7}$ & -6.64 & -0.10 & -10.38 & -25.32 & -29.79 & 6.93 & 12.64 \\
$\mathbf{3 x 8}$ & 0.61 & 5.08 & 5.62 & -10.10 & -45.63 & -5.45 & 19.55 \\
$\mathbf{4 x 5}$ & -33.48 & -10.73 & -26.70 & -37.77 & -26.73 & -7.56 & -41.53 \\
$\mathbf{4 x 6}$ & -26.04 & -14.45 & -30.52 & -37.47 & -31.95 & -10.40 & -29.28 \\
$\mathbf{4 x 7}$ & -15.93 & -9.66 & -24.63 & -22.61 & -27.50 & -5.68 & 2.01 \\
$\mathbf{4 x 8}$ & -1.66 & 4.83 & 1.35 & -11.78 & -34.04 & 1.56 & 14.53 \\
$\mathbf{5 x 6}$ & -47.31 & -26.44 & -34.11 & -42.66 & -28.66 & -11.24 & -63.85 \\
$\mathbf{5 x 7}$ & -30.08 & -18.23 & -22.77 & -23.92 & -17.25 & 4.78 & -24.12 \\
$\mathbf{5 x 8}$ & -19.29 & -11.96 & -9.22 & -17.97 & -27.94 & 8.63 & -10.70 \\
$\mathbf{6 x 7}$ & -23.66 & -19.59 & -27.40 & -30.22 & -27.31 & -0.25 & -22.74 \\
$\mathbf{6 x 8}$ & -45.40 & -47.59 & -1.69 & -3.86 & -36.53 & -1.63 & -13.98 \\
$\mathbf{7 x 8}$ & -2.91 & -9.39 & -0.79 & 7.62 & -30.52 & 9.90 & 24.36 \\
\hline $\mathbf{A v e r a g e}$ & -23.19 & -13.07 & -20.14 & -25.66 & -22.29 & -5.33 & -27.85 \\
\hline
\end{tabular}

